\title{
The Effect of Oral Galactose on GIP and Insulin Secretion in Man
}

\author{
L. M. Morgan, J. W. Wright, and V. Marks \\ Department of Biochemistry, Division of Clinical Biochemistry, University of Surrey, Guildford, England
}

Summary. The insulinotropic effect of $50 \mathrm{~g}$ galactose given orally to 5 normal volunteers on two occasions - once with and once without a period of hyperglycaemia produced by an intravenous glucose infusion - was studied. Oral galactose caused a rise in plasma GIP from fasting levels of $260 \pm 50 \mathrm{ng} / \mathrm{l}$ (mean $\pm \mathrm{S}$. E. M.) to a maximum of $900 \pm 65 \mathrm{ng} / 130 \mathrm{~min}$ after ingestion, but in the presence of induced hyperglycaemia the GIP response was significantly diminished and delayed (maximum plasma GIP levels $595 \pm$ $110 \mathrm{ng} / \mathrm{l}$ at $45 \mathrm{~min}, \mathrm{p}<0.05$ ). The insulin response to galactose was greatly enhanced by IV glucose (mean area under plasma insulin curve with galactose alone $236.5 \pm 66.0$, with galactose + IV glucose $451.9 \pm$ $81.6, \mathrm{p}<0.025)$. The mean rise in plasma galactose was significantly lower in the presence of IV glucose (mean peak level $1.97 \pm 0.28 \mathrm{mmol} / \mathrm{l}$ with galactose alone, $0.69 \pm 0.16 \mathrm{mmol} / \mathrm{I}$ galactose + IV glucose, $\mathrm{p}$ $<0.025$ ). Oral galactose caused the release of GIP, which is powerfully insulinotropic in the presence of moderate hyperglycaemia. The lower plasma GIP and galactose levels observed following oral galactose in the presence of IV glucose may be accounted for either by postulating that insulin inhibits the absorption of oral galactose, or that insulin exerts a negative feed-back control on GIP release and accelerates galactose disposition in the body.

Key words: GIP, oral galactose, insulin secretion, enteroinsular axis, induced hyperglycaemia.

Glucose stimulates insulin secretion by direct action on the B-cell as well as by the liberation of intestinal insulin releasing hormones. Galactose, on the other hand, though capable of stimulating insulin secretion when taken orally [8] fails to do so when administered intravenously $[6,8]$. This suggests that the insulin stimulatory effect of oral galactose is mediated largely, if not entirely, through its capacity to release one or more of the intestinal insulin-releasing hormones. At present, GIP is the major contender for the role of intestinal mediator of insulin release [3].

We have therefore investigated the insulin and GIP stimulatory properties of galactose in a group of normal healthy volunteers on two occasions; once after the ingestion of galactose alone and once after the ingestion of galactose during the course of an intravenous infusion of glucose.

\section{Materials and Methods}

Five healthy volunteers drawn from amongst the laboratory staff participated in the experiments. Three were men and two were women and their ages ranged between 25 and 35 years. All were within $10 \%$ of ideal body weight and had been eating a normal diet containing not less than $200 \mathrm{~g}$ carbohydrate per day until the evening preceding the tests. None of the volunteers were taking any drugs at the time of study.

Each subject attended the laboratory on two occasions having fasted since $2000 \mathrm{~h}$ the previous evening. A plastic cannula was inserted into an antecubital vein and kept patent with sodium citrate solution $(130 \mathrm{mM})$ to facilitate sample collection. On one of the two occasions a butterfly needle was inserted into an antecubital vein in the opposite arm through which a bolus injection of glucose $(25 \mathrm{ml}$ of $50 \mathrm{~g} / 100 \mathrm{ml}$ ) was given followed immediately by a constant intravenous infusion of $10 \mathrm{~g} / 100 \mathrm{ml}$ glucose at a rate of $0.25 \mathrm{~g} / \mathrm{kg} / \mathrm{h}$ for three hours. On both occasions at $1000 \mathrm{~h}$, one hour after the experiment had begun, the subjects drank $50 \mathrm{~g}$ galactose dissolved in $300 \mathrm{ml}$ of chilled water flavoured with lemon juice (final pH 4.0). Blood was collected at frequent intervals before and during the course of the experiments. Some was preserved in fluoride for later analysis for glucose content by an automated glucose oxidase technique [11]. Some of the blood was put into a lithium heparin tube, the plasma separated immediately and used for galactose analysis by a galactose dehydrogenase technique (Boehringer-Mannheim kit cat. no. 124273). The rest of the sam- 


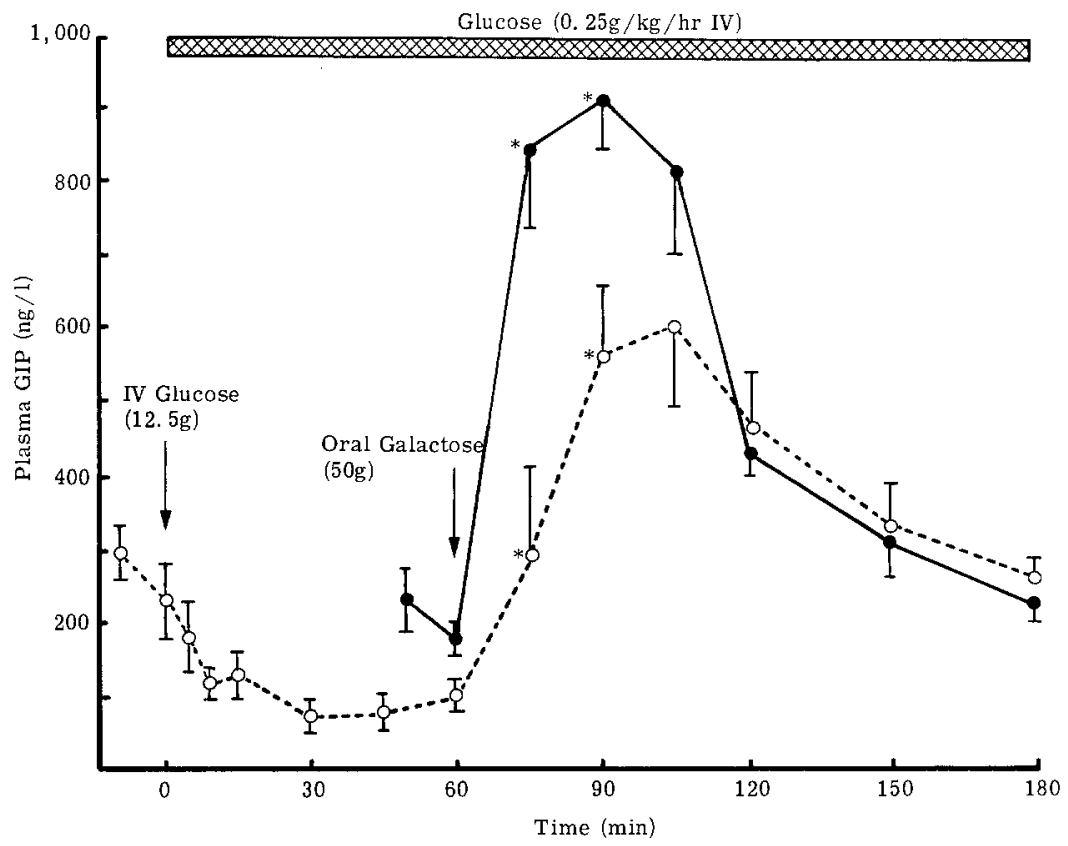

Glucose $(0.25 \mathrm{~g} / \mathrm{kg} / \mathrm{hr}$ IV $)$

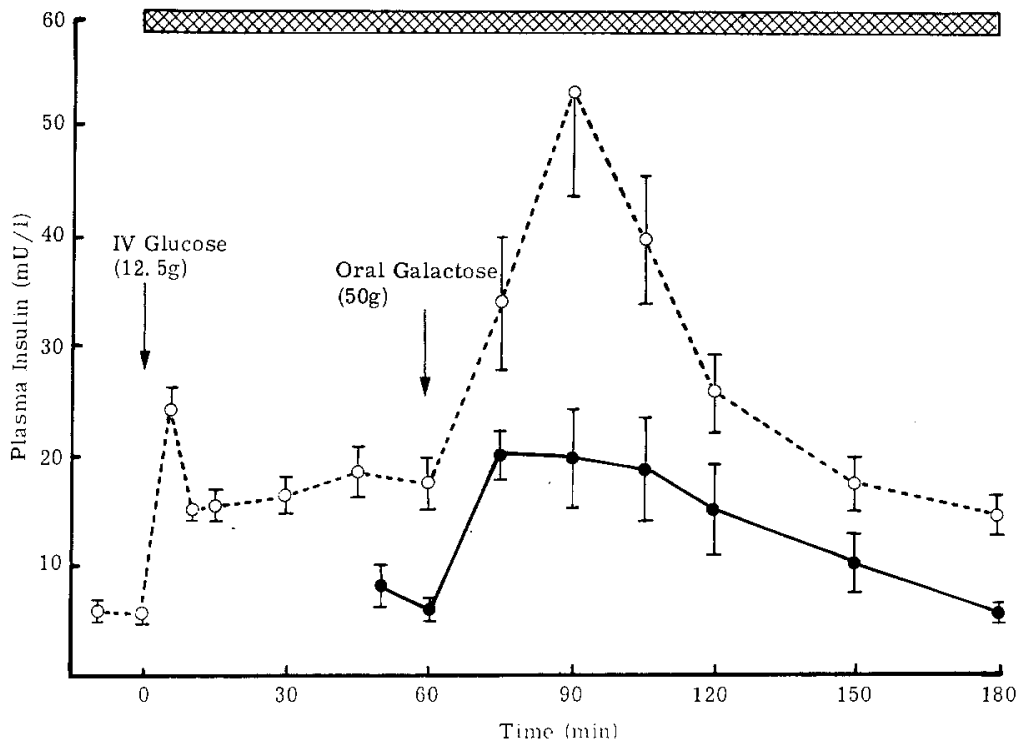

Fig. 1. Effects of the ingestion of galactose either with or without intravenous glucose infusion on plasma immunoreactive GIP, in 5 normal subjects. $(-=$ galactose alone $0-\ldots=$ galactose + i. v. glucose, $\boldsymbol{\Phi}=$ mean \pm S. E. M. ${ }^{*} p<0.05$ )
Fig. 2. Effects of the ingestion of galactose either with or without intravenous glucose infusion on plasma immunoreactive insulin, in 5 normal subjects. $(-=$ galactose alone, $0 .---0=$ galactose $+i$. v. glucose, $\overline{\boldsymbol{Q}}=$ mean \pm S. E. M.) ple was put into lithium heparin tubes containing sufficient aprotinin to produce a final concentration of $500 \mathrm{k}$. i. units $/ \mathrm{ml}$ blood. The mixture was centrifuged immediately, the plasma separated, frozen and stored at $-20^{\circ} \mathrm{C}$ until assayed for immunoreactive insulin [14] and GIP [10].

Measurement of GIP was by radioimmunoassay using a rabbit antiserum raised against porcine GIP, using porcine GIP standards. The assay was able to distinguish $70-110 \mathrm{pg} / \mathrm{ml} \mathrm{GIP} \mathrm{from}$ zero in plasma samples. The antiserum showed less than $1 \%$ cross reactivity with glucagon, GIP, secretin, pancreatic polypeptide, insulin or C-peptide. Preliminary work indicates that the anti- serum can recognise big GIP (MW 8,000 Daltons) and standard GIP (MW 5,300 Daltons). (O’Dorisio, T., Personal communication).

The "galactose-only" tests were carried out first; the infusion experiments later. The subjects sat comfortably, at ease, in the investigation unit throughout their performance. None of the subjects experienced abdominal or other discomfort at any time during the tests. The results were compared using Student's paired- $t$ test. Informed consent was obtained from all subjects, and permission to carry out the experiments was obtained from St. Luke's Hospital ethical committee. 

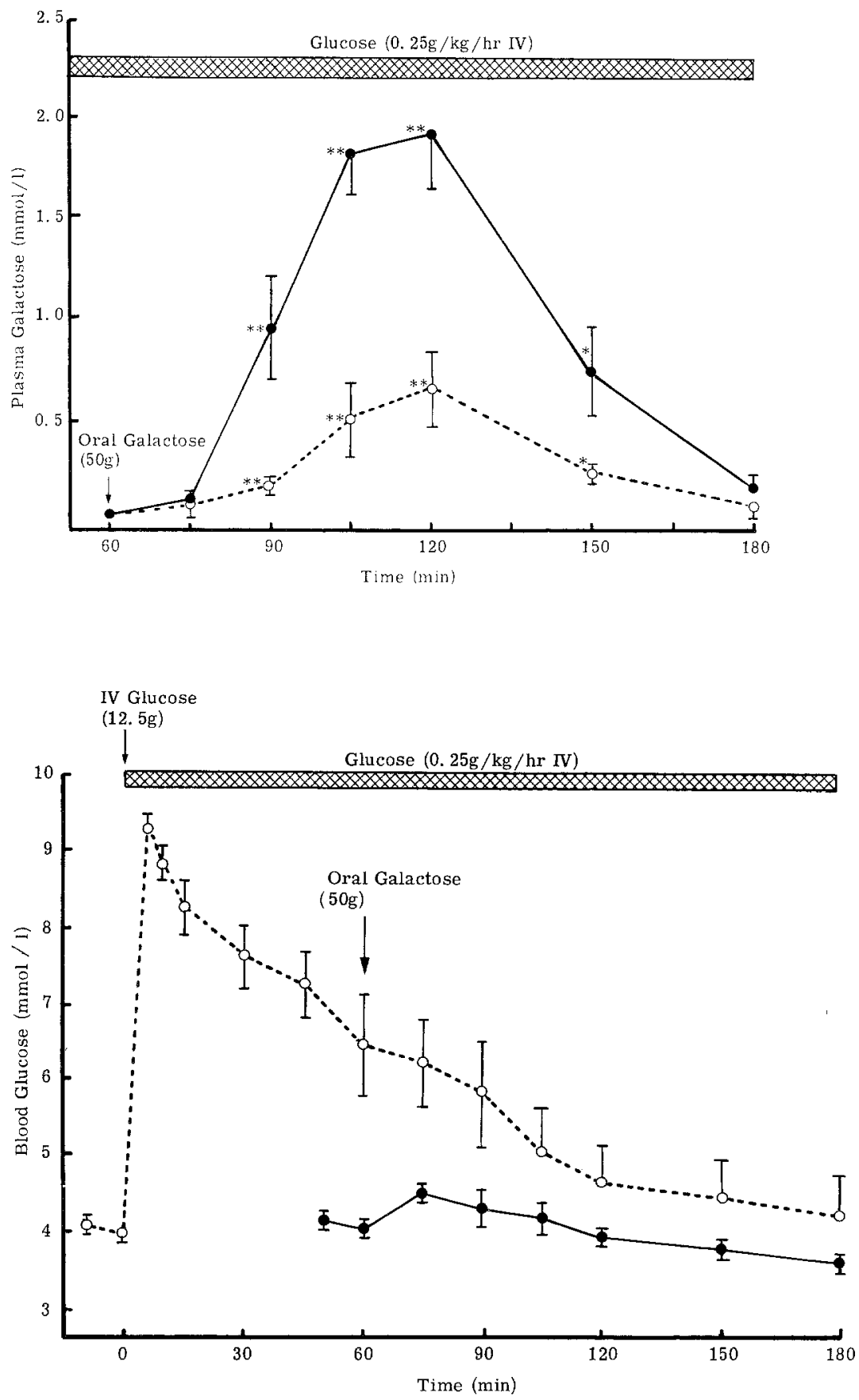

Fig. 3. Plasma galactose levels attained following the ingestion of $50 \mathrm{~g}$ galactose either with or without intravenous glucose infusion, in 5 normal subjects. $(-1=$ galactose alone, $\mathrm{O}-\ldots \mathrm{O}=$ galactose + i. v. glucose, $\overline{\mathbf{Q}}=$ mean \pm S. E. M. ${ }^{*} \mathrm{p}<0.05,{ }^{* *} \mathrm{p}<0.025$ )

Fig. 4. Effects of the ingestion of galactose either with or without intravenous glucose infusion on blood glucose, in 5 normal subjects. $(-0$ galactose alone, $\bigcirc----\circ=$ galactose $+i$. v. glucose, $\boldsymbol{\phi}=$ mean \pm S. E. M.)

\section{Results}

The results of the two series of experiments are summarised and compared in Figures 1-4.

\section{Oral Galactose Alone}

The ingestion of galactose was followed in every case (Fig. 1) by a large and rapid rise in plasma GIP (mean peak level $900 \pm 65 \mathrm{ng} / 1$ at $30 \mathrm{~min}$ ) and a small (Fig. 2) rise in plasma insulin levels. Plasma galactose levels rose slowly at first, reaching a peak (mean peak level $1.97 \pm 0.28 \mathrm{mmol} / \mathrm{l}$ ) at $60 \mathrm{~min}$ and had returned almost to basal values by $120 \mathrm{~min}$ (Fig. 3). Blood glucose showed a small but significant rise during the first $45 \mathrm{~min}$ following the ingestion of galactose (Fig. 4) but had returned to baseline values, or below, by $90 \mathrm{~min}$. 


\section{Intravenous Glucose Plus Oral Galactose}

Bolus injection, followed by continuous infusion of glucose, produced a rapid rise both in blood glucose and plasma insulin levels (Figs. 2 \& 4). Blood glucose levels reached a peak within five minutes of the bolus injection and fell slowly thereafter despite constant intravenous infusion of glucose at the rate of $0.25 \mathrm{~g} /$ $\mathrm{kg} / \mathrm{h}$ (Fig. 4). Plasma insulin levels rose rapidly initially (Fig. 2) but fell almost equally rapidly to a new supra-basal plateau. Thereafter, plasma insulin levels remained more or less constant until the ingestion of oral galactose when they rose once again, this time to a level considerably higher than after galactose alone $(53.3 \pm 10.7 \mathrm{mU} / 1$ v. $20.5 \pm 2.8 \mathrm{mU} / \mathrm{l})$. Comparison of the total area under the plasma insulin curve following the administration of oral galactose (from 60-180 min) showed a significantly greater insulinaemic response to galactose given during the IV glucose infusion than when galactose was given alone. (Area under curve with galactose alone, 236.5 \pm 66.0 , with galactose + IV glucose $451.9 \pm 81.6$, $\mathrm{p}<0.025$ estimated using the $60 \mathrm{~min}$ plasma insulin level as a baseline).

Plasma GIP levels declined slowly and significantly throughout the period of intravenous glucose infusion until interrupted by the ingestion of galactose (GIP levels between 10 and $60 \mathrm{~min}$ being significantly lower $(\mathrm{p}<0.05)$ than plasma GIP at zero time). Thereafter, plasma GIP levels rose (mean peak level $595 \pm 110 \mathrm{ng} / \mathrm{l}$ at 45 minutes) though more slowly and to a significantly lesser extent than after oral galactose alone. Plasma galactose levels (Fig. 3) showed a consistently smaller rise ( $p<$ $0.025)$ than when galactose was ingested in the absence of an intravenous glucose infusion.

\section{Discussion}

The work reported here indicates that, in man, galactose ingestion, like that of glucose [3] is associated with a large brisk rise in plasma GIP concentrations. Reports of the GIP releasing properties of galactose are conflicting. Of the three abstracts relating to GIP release in dogs after oral galactose, two report a rise in plasma GIP levels - albeit a rather small one - and one no significant change $[9,16,18]$. One recent communication [13] relating to man reports a small rise in plasma GIP levels after oral galactose.

GIP is relatively ineffective in stimulating insulin release except in the presence of mild to moderate hyperglycaemia [3]. This may account for some of the reported failures to observe a rise in plasma insulin levels following oral galactose administration [1].
Since the insulinotropic effect of GIP is enhanced by hyperglycaemia we decided to compare the GIP releasing and insulinotropic effects of oral galactose in the presence and absence of induced hyperglycaemia. It did not prove possible, as had been intended, to maintain a constant blood glucose concentration throughout the period of induced hyperglycaemia. Nevertheless, even in the presence of a declining blood glucose concentration the administration of $50 \mathrm{~g}$ galactose by mouth was promptly followed by a large rise in plasma insulin concentration.

A small rise in blood glucose concentration is commonly, though not invariably, observed during the first hour following ingestion of galactose as in the present series of experiments. We suggest that this small rise in blood glucose concentration makes the B-cells of the pancreas receptive to the rise in plasma GIP levels produced by oral galactose and indirectly responsible, therefore, for the modest rise in plasma insulin concentration observed when galactose is ingested alone $[8,15]$. The much larger rise in plasma insulin provoked by the ingestion of galactose in the artificially induced hyperglycaemic subjects was associated with a significantly smaller and delayed rise in plasma GIP concentration. The reduction in plasma GIP response to oral galactose under these circumstances could be accounted for by operation of a negative feedback control of GIP secretion by insulin [3]. It could, however, be due to inhibition of galactose absorption.

The much lower plasma galactose level observed when the subjects drank their galactose solution whilst receiving IV glucose compared with when they drank it alone, was unexpected. Addition of glucose into the gut has been reported to interfere with active jejunal galactose transport to different degrees in various species $[5,12]$. It appears unlikely that IV glucose could act in this way, although the possibility must be considered that hyperglycaemia in some way delays gastric emptying - possibly by inhibition of motilin secretion (Bloom, S. R., personal communication). Beyreiss and co-workers [2] reported the inhibition of galactose absorption from the gut in rabbits by the infusion of exogenous insulin. The higher endogenous insulin levels attained when our human subjects received IV glucose could therefore interfere with their galactose absorption. Another explanation of the lower rise in plasma galactose levels when subjects were receiving IV glucose is that whilst galactose absorption is unchanged by this manoeuvre, its clearance from the plasma is increased as a result of the greater hyperinsulinaemia. Most cells of the body - with the notable exception of those in the liver - are virtually impermeable to glucose and 
galactose, except in the presence of insulin $[4,7,17]$. Oral galactose alone is a poor stimulus to insulin secretion and consequently galactose is excluded from entry into all but liver cells. However, the higher insulin levels attained when subjects received IV glucose could render peripheral tissues more permeable to galactose. Animal experiments have shown that exogenous insulin increases galactose removed from the blood and its entry into peripheral tissues $[6,7$, 17] where it is probably metabolised by a pathway not involving the enzyme galactokinase.

The role of insulin is regulating the metabolism of galactose has largely been ignored in the past, probably because, under most experimental conditions it does not stimulate insulin secretion - or does so to only a slight extent. Under most natural conditions of usage, however, namely when consumed as lactose, galactose can and does stimulate insulin secretion which could then proceed to play a part in its metabolism.

\section{References}

1. Ambrus, J. L., Ambrus, C. M., Shields, R., Mink, I. B., Cleveland, C.: Effect of galactose and sugar substitutes on blood insulin levels in normal and obese subjects. J. Med. 7, 429-432 (1976)

2. Beyreiss, K., Muller, F., Strack, E.: Über die Resorption von Monosacchariden. I. Der Einfluß von Insulin auf die Resorption der Galaktose. Z. Ges. Exp. Med., 138, 277 (1964)

3. Brown, J. C., Dryburgh, J. R., Ross, S. A., Dupré, J.: Identification and actions of gastric inhibitory polypeptide. Recent Prog. Horm. Res. 31, 487-532 (1975)

4. Goldstein, M. S., Henry, W. L., Huddlestun, B., Levine, R.: Action of insulin on transfer of sugars across cell barriers: common chemical configuration of substances responsive to action of the hormone. Am. J. Physiol. 173, 207 (1953)

5. Holdsworth, C. D., Dawson, A. M.: The absorption of monosaccharides in man. Clin. Sci. Mol. Med. 27, 371-379 (1964)

6. Kvam, D. C.: Lack of effect of tolbutamine upon certain insulin-responsive sugars. Proc. Soc. Exp. Biol. Med. 115, 904-906 (1964)

7. Levine, R., Goldstein, M. S., Huddlestun, B., Klein, S. P.:
Action of insulin on the "permeability" of cells to free hexoses as studied by its effect in the distribution of galactose. Am. J. Physiol. 163, 70-83 (1950)

8. Marks, V., Samols, E.: Action de différents stimuli (galactose, fructose, et lipides) sur l'insulin sécrétion humaine: influences du tractus gastro-intestinal. J. Annu. Diabetol. Hôtel Dieu 9, 179-190 (1969)

9. Martin, E.W., Sirinek, K. R., Crockett, S. E., O'Dorisio, T. M., Mazzaferri, E. L., Thomford, N.R., Cataland, S.: Release of gastric inhibitory polypeptide: comparison of hyperosmolar carbohydrate solutions as stimuli. Surg. Forum 26, 381-382 (1975)

10. Morgan, L. M., Morris, B. A., Marks, V.: Radioimmunoassay of gastric inhibitory polypeptide. Ann. Clin. Biochem. 15, 172-177 (1978)

11. Morley, G., Dawson, A., Marks, V.: Manual and autoanalyser methods for measuring blood glucose using guaicum and glucose oxidase. Ann. Clin. Biochem. 5, 42-45 (1968)

12. Ricklis, E., Haber, B., Quastel, J. H.: Absorption of mixtures of sugars by isolated surviving guinea pig intestine. Can. J. Biochem. 36, 373--380 (1958)

13. Ross, S. A., Dupré, J.: Effects of ingestion of triglyceride or galactose on secretion of gastric inhibitory polypeptide and on responses to intravenous glucose in normal and diabetic subjects. Diabetes 27, 327-333 (1978)

14. Samols, E., Bilkus, D. A.: A comparison of insulin immunoassays. Proc. Soc. Exp. Biol. Med. 115, 79-84 (1964)

15. Shima, K., Kuroda, K., Matsuyama, T., Tarui, S., Nishikawa, M.: Plasma glucagon and insulin responses to various sugars in gastrectomized and normal subjects. Proc. Soc. Exp. Biol. Med. 139, 1042-1048 (1972)

16. Sirinek, K. R., Thomford, N. R., Pace, W. G., Crockett, S. E., O'Dorisio, T. M., Mazzaferri, E. L., Cataland, S.: J. Surg. Res. (in press) (1978)

17. Wick, A. N., Drury, D. R.: Action of insulin on volume of distribution of galactose in the body. Am. J. Physiol. 173, 229-232. (1953)

18. Williams, R. H., Biesbroek, J.: Effect of single food components on plasma GIP. Diabetes 26, 374 (1977)

Received: July 28, 1978

and in revised form: November 28, 1978

Dr. L. M. Morgan

Department of Biochemistry

University of Surrey

Guildford, GU2 5XH

England 